\title{
Teaching intercultural competence: Dialogue, cognition and position in Luke 10:25-37
}

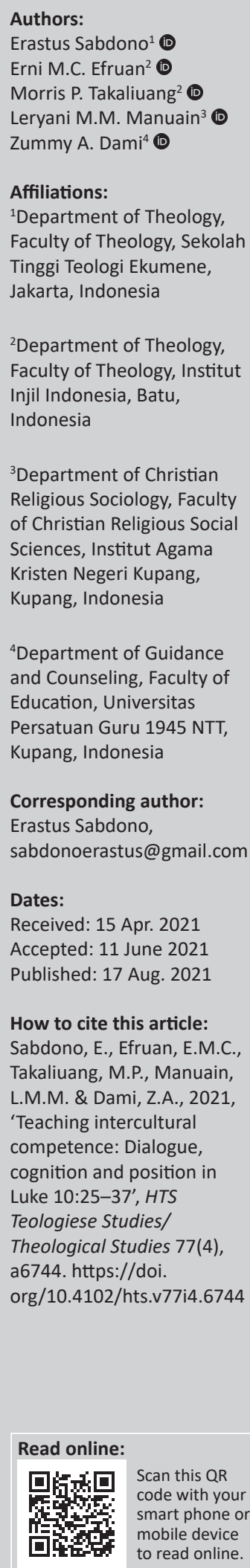

This research aimed to know the intercultural competency teaching model of Jesus (Teacher) using a parable technique based on Luke 10:25-37 to improve intercultural competence. The authors used a method of diacognitive analysis with three lenses that include dialogue, cognition and position. The results of the study have shown that the application of the parable technique can improve the competence of intercultural students (the expert in the law) towards people with different cultures (Samaritan), as well as increase the understanding and awareness that love is the basis of intercultural competence, compassion as an internal outcome and must act as an intercultural agent. The teacher's pyramid model of intercultural competence moves from love, attitude, knowledge, skill, internal outcome, external outcome and becomes an intercultural agent.

Contribution: Research on Luke 10:25-37 has shown that the parable technique can improve students' intercultural competence based on love and compassion. Teachers can apply parable techniques to attract, encourage, and stimulate the student's active involvement to think critically and perform interpretations to discover the real truth in the context of cultural differences.

Keywords: teaching; intercultural competency; parable; diacognitive analysis; cognition; dialogue; position.

\section{Introduction}

The ability to interact successfully and respectfully with persons from other cultures and religious backgrounds is a highly desired and helpful competence. The Teacher who is better at navigating through challenging intercultural contexts performs better at work and has a favourable influence on its students (Leung, Ang \& Tan 2014:490). The fundamental responsibility of a teacher is to educate pupils for professional achievement. As a result, offering particular intercultural learning opportunities for students is a critical task for educational institutions (Lee et al. 2012:202).

Intercultural competence (IC) is defined as the ability to communicate effectively and appropriately in an intercultural situation based on knowledge, skills and intercultural attitudes of a person (Deardorff 2006:194), or in other words, it is the ability to understand change in cultural perspectives and adapt behaviours to face cultural differences (Valdivia, Marlene \& Iosbel 2018:2). Based on the definition, it can be composed of essential basic components of IC, which includes attitudes (respect, openness, curiosity and discovery), knowledge (cultural self-awareness, culture-specific knowledge, sociolinguistic awareness grasp of global issues and trends) and skills (listening, evaluating, analysing, interpreting and relating and critical thinking) (Byram, Gribkova \& Starkey 2002:45; Howard-Hamilton, Richardson \& Shuford 1998:10).

The three components of IC are adopted in this study, which explains that: (1) IC is a flexible and enjoyable competency in a different cultural state with the power of understanding and knowledge of one's own culture and other people's cultures (cognitive aspects), (2) attitudes towards cultural learning and intercultural differences (affective aspects) and (3) the skill to cope with different cultures effectively (behavioural aspects) (Zhang \& Zhou 2019:32). According to Deardorff, this is a pyramid model - looking at the development of IC as a process that moves from the personal level (attitude) to the interpersonal level of interaction with others (outcomes) (Deardorff 2006:255).

Of course, the hope of IC implementation cannot run naturally because there are always problems - people do not understand and perform the commandments of God: Love God and love thy neighbour as yourself. The most concrete example of the IC problem was the relationship between Jews and Samaritans. The Jews regarded the Samaritans as a mixed-race of people, outgroup, impure, ignored God and were seen as a corrupt form of ethnic Jews because they were the result

Copyright: ( 2021. The Authors. Licensee: AOSIS. This work is licensed under the Creative Commons Attribution License. 
of mixed marriages between Jews and Gentiles, or nations deemed immoral, pagan and idolatrous (Knoppers 2013:111; MacArthur 2006:65-67; Wahona 1986:338-339). Consequently, both Ezra and Nehemiah opposed the mixed-marriage to the Samaritans. When the Samaritans offered to help Nehemiah rebuild the walls of Jerusalem, they were only given the brief word 'no thanks'. (Voorwinde 2011:30). In truth, when travelling to the northern area, particularly Galilee, Jewish leaders travelled via Samaria, which was the shortest path geographically, but they took an alternate and longer route to not pass through Samaria (MacArthur 2006:67).

Furthermore, the Jews considered the Samaritans' worship to be wicked. This is indicated because the Samaritans believed the holiness of the Temple on Mount Gerizim was not in Jerusalem. As a result, this is the central point of contention between Jews and Samaritans. Mor (1989:18) notices that the Samaritans were historically shunned by Jews purely on religious grounds - religious disputes led to the destruction of the Samaritan sect. In conclusion, Sales (2020:10) confirms that the Samaritans were excommunicated both socially and religiously from the Kingdom of Judah in the south as noticed within the text 'Jews have no dealings with Samaritans' (Jn 4:9). This problem is also still happening to this day in the setting of education, where diversity is rejected and conversely, there is a drive to impose similarities, uniformity and standard of behaviour for the sake of cohesion (Bennett 2004:63; Pinyol-Jiménez 2016:98). Consequently, education is more oriented to ethnocentrism than to ethnorelativism.

This empirical evidence suggests that no understanding and application of love and compassion impacts the bad and low IC that will lead to negative prejudice, discrimination and unfriendly words, which directly have misunderstandings of others with different cultural backgrounds, resulting in a lack of recognition, reverence and acceptance of others' cultural richness, and thus not living in harmony and tolerance (Barrett 2011:25).

The big educational challenge is to unlearn the rejection of variety and instead learn to accept it in order to create new educational options based on intercultural attitudes and behaviours (Armstrong, Armstrong \& Spandagou 2011:30). In particular, researchers and educators are investigating how teaching strategies are perfect for building IC in culturally and religiously diverse socio-educational environments. Interventions that can be implemented to improve IC include intercultural training (Santerini 2010:188); international trips (Santoro 2014:429); professional development programmes (Teräs \& Lasonen 2013:107); study-abroad programmes (Kasmer \& Billings 2017:14; Ramirez 2016:88); Culturally diverse group work (Arshavskaya 2018:194; Brendel et al. 2016:284; Jin 2015:38); civic engagement experiences (ShahGordon 2016:25); reflexive thought (Matthews 2020:330); pedagogical interventions that include classroom activities, integrated intercultural programmes, culture-based teaching materials and comprehensive teaching strategies (Feng 2016:4; Gowindasamy 2017:168; Liu 2018:123; Rodríguez \& Carranza 2017:79; Stockwell 2016:649; Williams 2017:18); overseas immersion (Zhang \& Zhou 2019:42) and heavy metal music (Guberman 2020:1). All of these interventions use research designs that include experiment, quasi-experiment, mixedmethods and action study and are more dominant using Deardorff's pyramid model of IC. Besides, the story of the parable of the Good Samaritan was examined by previous researchers (Efruan \& Dami 2019:301; Efruan et al. 2020:165; Esler 2000:351-352; Rule 2017:7-8; Wauran 2016:1; Wibowo 2000:223), but the four previous studies did not explain the parable related to teaching IC.

Among all the studies, there has been no research using the parable technique as part of the IC teaching model with diacognitive analysis design (dialogue, cognition and position) in Luke 10:25-37 to improve IC. Based on this, the purpose of this study is to know the intercultural competency teaching model of Jesus (Teacher) using a parable technique based on Luke 10:25-37 to improve IC.

\section{Research methods}

This study uses a circular method of hermeneutics version Schleiermacher. According to one version of the hermeneutic circle, the reader moves back and forth between the text and its context (Stausberg \& Engler 2011:276-277) and the design of the research is a diacognitive analysis of Luke 10:25-37. Diacognitive analysis is based on Freire's (2004:123) thought concept, which emphasises that learning and teaching is an event in the process of knowing something more in-depth and broader, or, in other words, a conceptual framework for understanding and analysing a learning and teaching event that connects learners with the process of knowing something more in-depth and broader (Rule 2015:42). Diacognitive analysis consists of three lens layers that provide a difference, but have perspectives that complement each other and are mutualistic and are always placed within the conversation context. These three lenses include dialogue, cognition and position. The dialogue is understood as communication that focusses on the nature of one's involvement in learning and teaching situation that includes interpersonal, intrapersonal, transpersonal and intratextual dialogue. Cognition focusses on the process that goes into coming-to-know, more than knowledge as a material or object. The object of cognition is something known - skills, procedures, a series of relationships, perspectives and stories or parables. Cognition is always purposeful because it comprises a subject (knower) who focusses on knowing objects. Furthermore, cognition is always embedded in a specific environment that defines and informs the meaning-making process. Position refers to the participants' 'placeholders' in a dialogue such as self-position and reposition.

\section{Why use a parable?}

Making analogies is at the heart of the parable's discussion (Donahue 1988:5; Vermes 2003:6). Furthermore, the Bible explains that a parable includes not only narrative comparisons but also proverbs, wise words and allegory, as evidenced by the parable of the sower, the story of the prodigal son, ye cannot serve two masters, the widow and the unjust judge, 
the foolish rich man, the vine and the branches, the bread of life and the 10 virgins and the salt of the earth. Dodd (1961:16) insists that the parable is a metaphor or simile drawn from nature or everyday life, arresting the hearers by its vividness or strangeness and leaving the mind in sufficient doubt about its precise application to tease it into active thought.

The Parable of Jesus has four traits: (1) An oral form (which draws the attention of the listener). In a specific setting with oral interactions, the speaker delivers the parable to the audience. The parable is an oral story (Funk, Scott \& Butts 1988:17); (2) A parable is a picture of a word or short narrative based on comparison and a character recognisable to the audience, or in other words, the parable is based on nature, everyday life and the normal circumstance of what everyone knew and accepted with confidence. Hoyer and McDaniel (1990:332) conclude that although Jesus was telling the story, Jesus also spoke about reality. It has two meanings: literal and metaphorical, which implicitly and explicitly send cues (Zimmermann 2008:137); (3) The parable is open-ended and invites listener engagement. James added another feature of the parable, namely frankness to listeners, simplicity, symmetry, focus on the human character and the parable also moves the imagination and stimulates personal quest (James, Martinez, \& Herbers 2015:131). Furthermore, because Jesus saw the parable as a technique of concealing the explicit meaning of the topic being given, listeners must engage in critical reflection (critical thinking) in order to comprehend the tale's meaning - hear with your heart, not your ears alone.

Through the parable in Luke 10:25-37, Jesus showed the reader something essential about his life philosophy. That is, a person's general view of the world affects his or her behaviour; otherwise, a person's behaviour affects his or her general view of the world (Horne 1920:89-90). The Parable of Jesus demonstrates the supremacy of the spiritual, but in the region of thought (Horne 1920:89). A parable is a careful tool to manifest the truth to a friend or hide the truth from an adversary. The parable is the beauty of truth - the truth to nature and humans in the divine aspect. In short, the parable is unity between the real and the ideal, the real material with the ideal spiritual or in other words, the poem of Heaven with the prose of earth. This unity appears in the parable's story in Luke 10:25-37, there is the material real and spiritual ideal, but the virtue is embodied in the story itself (Horne 1920:82). In the end, Snodgrass (2008:1) confirms that there is no vitality, relevance and usefulness from Jesus' very clear teaching as in his parable.

One of the reasons Jesus adopted this parable technique in the midst of his public ministry (Lk 10:25-37) was because of the emergence of the opposition (the expert in the law) who opposed Jesus, and the use of parable as one way of selfprotection in his teaching - enabled Jesus to endure until his time came (Horne 1920:81). This indicates that the technique of parables is suitable for teaching IC because it does not seem neutral, impartiality, attacking student's personal and truth-oriented and safe for the teacher. In addition, the parable is compatible with the three components of IC, where the parable moves the listener to understand the general view of the world and realise his or her own culture and other people's cultures with knowledge. Thus, stimulating the listener to have an open attitude to a variety of possible meanings and have an attitude towards personal quest (attitude) and attract listeners to interpret and think critically about the meaning of the parable (skills).

\section{Parable: dialogue}

Intercultural education aims to go beyond passive coexistence in order to create a better developed and sustainable way of living in a multicultural society by instilling a sense of respect and conversation among various ethnic groups (UNESCO 2006:18). Based on this purpose, intercultural teaching is divided into two parts, namely inclusion and participation (pluralism and equality) and learning to live together - a feeling of having a broader community based on mutual respect and a shared belief in the dialogue (Batelaan 2003:4).

Dialogue has a very important role in improving intercultural competencies and the parable is a dialogue on some levels. A dialogue between Jesus (Teacher) and the expert in the law (student) takes the shape of an intermittent sequence of questions and responses on an interpersonal level. The first question posed by the student was, 'What must I do to obtain eternal life?' 'What is written in the Law?' the Teacher responded with a question. 'Love God and love your neighbor', a student replied to the Teacher's inquiry. The Teacher approves and validates an answer from a student. In this section, the dialogue is suddenly interrupted - Nikulin (2010:78) calls it 'the termination of dialogue', and the Teacher wants to show that the student's question is not an authentic quest to know something real. The student then asked a second question, 'And who is my neighbour?' The Teacher replied by telling a parable. Afterwards, the Teacher asks the student a question, 'Which of these three do you think was a neighbour ...?' The student replied, 'The one who had compassion on him'. At this stage, the Teacher commanded, 'Go and do likewise'. The Teacher does not respond at this point, but rather encourages the student to respond to his question in one of two ways: using his understanding of the Law to interpret the parable and using the parable to answer his second question. The Teacher employs a dialogical format to elicit thought from the student and to challenge him to reach a conclusion. In this perspective, Matusov (2011:22) sees that the Teacher used a dialogical intercultural strategy to develop the 'dialogic provocation'. A 'dialogic provocation' will involve students ontologically with something that excites and appeals to them - this is the primary use of the parable technique (Zimmermann 2015:270).

The intrapersonal dialogue explicitly indicates two things, including: (1) The student stood to test the Teacher (Lk 10:25). This indicates that the student was involved in the internal dialogue: 'How can I tempt this the Teacher?' I know, I will ask him... (2) The phrase, 'but he wants to justify himself' (Lk 10:29) states an internal conversation such as: 'He has shown me that I already knew the answer, how could I be able to hide my face?' I asked him: 'Who is my neighbour?' Implicitly, 
this dialogue indicates that each interlocutor internalises the other and formulate a response appropriately. For example, when the Teacher hears the first question of a student, the Teacher has an internal dialogue like: 'Why did he ask that question to me?' The student knew the answer, and he tested me. Therefore, I will change the question that relates to the things that are around him.

At the transpersonal dialogue level, the dialogue works in various ways, especially in this study; there are three things that the author will discuss: Firstly, there is a dialogue between genres: commandment (love your neighbour) and parable (The Good Samaritan). Secondly, a 'commandment' takes the form of an imperative and a 'parable' takes a declarative form. Thirdly, the 'commandment' is semantically closed and produces a response (obedient or disobedient) and the 'parable' is semantically opened and works through metaphors that require personal interpretation.

At the intratextual level, there is a conversation between and among the reactions of three characters who pass the halfdead person. The Priest and Levite were unconcerned; probably because they could not defile themselves by touching the corpse, as the commentators proved (Vermes 2003:33). The Samaritan, on the other hand, demonstrates compassion, attentiveness and responsibility. Because the Samaritans were considered as an exile and heretics in Jewish culture, there was an 'interesting strangeness' in this part. The idea that the Samaritan became 'neighbour' for the Jew was shocking for the Jewish audience, especially when they did not act like religious figures who were an example for them so far as priests and Levite. In connection to the interaction between the parable and the listener's socioreligious environment, the intratextual dialogue expresses the Samaritan's attitude to the half-dead man.

Finally, there is a dialogue between knowing and doing or cognising and practicing something. 'What must I do to inherit eternal life?' inquired the student. He expresses his desire to know what he should do. The student is curious and engaged in discovery learning in order to find the correct solution. The Teacher's answer shows a relationship between two things: (1) 'What is written in the Law' and (2) How did you read it? 'Knowing the Law arises from or includes a practice of reading or interpreting it. Students' answers indicate an understanding of what is required by the Law. Interestingly, the Teacher did not stop with the support of the student's answer: 'You have replied correctly' - you know the answer, but that is not enough: 'Do this and you will live'. The dialogue knows and does appear in and around the parable that the Teacher has told.

\section{Parable: position}

Position placements include taking a position in the conversation and simultaneously positioning others. The student takes a position as the questioner and the Teacher's position as a person who knows and has the power to answer the topic of conversation. The student's question implicitly contains a proposition about his interlocutor: 'You are a Teacher who can answer the question'. The Teacher chooses not to accept the position imposed by the student. More than that, the Teacher repositioned himself by answering with a question. The student accepted this position and proposed an answer: 'Love God and love your neighbour'. After that, the student made a proposition on how to inherit eternal life and about himself: 'I am a man who knows what is written in the Law' and how to read it' and I can memorise and pronounce it. This proposition contradicts its initial position as a questioner and states that the question is not an authentic investigation to know about how to inherit eternal life, but rather it is a test to the Teacher. The Teacher positions himself as an assessor of the validity of the proposition, and then effectively reverses the position of the student from the assessor to the assessee: 'You have answered correctly. Do this and you will live'. Here, the Teacher positions the student as a person who knows (knower) and a person who has cultural awareness and embodies his knowledge in practice (agent).

The student then repositioned himself as a questioner: 'And who is my neighbour' - once again the position of Teacher as a person who knows and has the power to answer. The Teacher accepted this position, but indirectly, and answered with a parable. Here, the Teacher departs from the formal language of the Law and commandments and enters a narrative language. In the conclusion of this parable, the Teacher adopted the position as the questioner and the student's position to answer. The student agreed and suggested that 'the one who offered him sympathy' was a robbed man's neighbour. The Teacher implicitly endorses the student's proposition and directs it to do the same, repositioning him as a person with IC and making him an agency.

\section{Parable: cognition}

The first object of cognition was introduced through the student's question, what to do to inherit eternal life. The student recognises this in his answer to the Teacher's question cognises again what he has known: love God and love your neighbour. The Teacher's response shows that he knows this. Because both the Teacher and the student know this answer, there is no new cognition object. What cognition arises from their dialogue? The Teacher knew the motivation of the student: 'Test him'. The student realised this; He learns that the Teacher knows his motivation: So, there is an intercognition among them about what his true motivations are. This leads him to recognise his motivation from the Teacher's perspective; apparently, the student is experiencing a 'temporary selfposition' of discomfort and perhaps shame. He devises a strategy to 'justify himself' and save face by asking an authentic question.

Finally, the student introduces a new object of cognition: Who is my neighbour? The Teacher realised that this was an authentic question and did not ask the student to answer. Instead, the Teacher told a parable. However, after telling the parable, the Teacher changed the object of cognition from 
'who is my neighbour?' to 'which of these three do you think was a neighbour to the robbed man?' Furthermore, the Teacher distracts the attention of the robbed, the victim, to the person who assisted him, an agent; from the expected object of cognition 'whom you should love' as a 'neighbour' to 'who loves as a neighbour'. This proves that the parable story is a surprising reversal, which changes the hope of the student (the Jews) to be reversed. The Teacher placed the student to identify the outside (culture) that was despised the Samaritan - an ignoble character in the first century in Palestine (Reinstorf 2013:2), not the Priest or Levite, who was an example of love, when they knew that the lying was Jewish - just as they were Jews - where it should be one of the main factors to move their hearts (Wibowo 2000:225-226). It is undoubtedly not very pleasing, if not offensive, for the student: 'Love your enemy but "my enemy loves me"; I have to like him'.

The parable and intercultural teaching of the Teacher demonstrates a specific relationship between knowing and doing, cognition and action. Not enough for students and listeners (Jews) to solve the puzzle of the parable by merely knowing, having cultural awareness or cognise of people who love their neighbour, but do not do so. Knowing and having cultural awareness or cognise is the first step leading to the next step: 'Go and do likewise'. The word 'likewise' refers to the metaphorical meaning of the parable, which means to know and do the learning of the parable in the complexities of daily life. As the Samaritan did, although it takes risks and costs. In conclusion, the Teacher's command invites open and living conversations between parable and practice.

In this sense, recognising the parable in the living practice begins from the beginning of the parable until it ends. The parable opens the opportunity to show one's love for one who cannot be established but can only be lived. In this context, participants must actively 'read the lives of others (cultures) and respond to the life as they listen and respond to the parable: 'Likewise' is a term that shows practical wisdom or acting appropriately and wisely (phronesis) in the contextual application: doing 'likewise' (imitating the Samaritan) and becoming 'likewise' (understanding when, who and how love neighbour who has a different culture with all the complexities of life). This is the heart of the cognition metaphor found in life practice as implied in the parable of the Teacher, as a provocative dialogue that invites a response.

\section{Teacher only}

The scribes referred to Jesus as the 'Teacher' at the start of the parable. Many people use the word 'Teacher' or 'rabbi', and it is offered to Jesus - as a self-designation (Stein 1994:78). Borg (2011:166) sees Jesus as the Teacher, neither as a bearer of information or knowledge, nor as a moral teacher who provides true or false information, but more than that, Jesus is seen as a Teacher of wisdom, who understands teaching style with particular forms of teaching (short words or stories) and unique teaching content (what is real or precious and how his disciples will live). As a teacher of wisdom, Spear (2005:355) sees Jesus' teaching as a counter wisdom (not cultural wisdom) aimed at transforming his listeners' intercultural consciousness, which he expressed in the parable.

Based on the selection of teaching techniques and the topic of the parable told by the Teacher shows that the Teacher understands precisely the motivation and character of the disciples in teaching, who tend to be legalistic or outward formalism, hypocrites (Mt 23:3; 23), and happy to test and seek reasons to blame him (Lk 6:7; 10:25). In this perspective, the Teacher wanted to declare that I am a Jew - having IC (attitude, knowledge, skill, internal outcome and external outcome) based on love, even though the Samaritan rejected me and moved by compassion; I rebuked James and John who wanted to destroy the Samaritans by fire from heaven (Lk 9:51-56). In Luke 10:25-37, the Teacher demonstrates the high IC in which the Teacher makes the Samaritans an intercultural hero because the Teacher wants to challenge his scribes and disciples against the Samaritan (Voorwinde 2011:42).

\section{Teacher and student}

The teacher taught through parables to improve the student's IC because the student does not have cultural self-awareness and understanding of Samaritan's worldviews. According to the conflict face negotiation theory (Ting-Toomey 2009:72), knowledge is the most important component of all intercultural competency components because: (1) People cannot learn to expose the ethnocentric lens they use to analyse behaviour in intercultural conflict interactions without culture-sensitive knowledge; (2) Without knowledge, people cannot have an accurate perspective or to frame their interpretation of the problematic communication situation of the cultural reference framework of the Samaritan; (3) Knowledge should be able to improve cultural self-awareness and other-awareness and knowledge can lead to an openminded attitude. Knowledge and open-mindedness are tightly tied and influence each other and (4) knowledge refers to developing the understanding of relevant intercultural concepts that can help manage cultural-based conflicts (TingToomey 2005:103). The research results show that knowledge is the most necessary component in IC, covering aspects of intercultural awareness or cultural self-awareness and understanding of other's worldviews (Deardorff 2006:249; Odağ et al. 2015:130).

The question today is, how can I improve the IC of the student? In the parable, the Teacher transforms the object of cognition from 'who is my neighbour?' to 'which of these three do you think was a neighbour to the robbed man? At this stage, the Teacher distracts his attention from the robbed victim to the person who helped him; from 'whom you should love' as a 'neighbour' to 'who loves as a neighbour'. It is a call to the student to question the assumption of his status, identity and position, indicating that it is not of whom thou, but your willingness to be touched from within, by the sufferings of others (Zimmermann 2015:270), and how you 
act as a crucial response in loving others who have different cultures. The Teacher teaches about loving others not being limited by culture, religion or anything else, no matter who they are when we love God, then we will love them too and will show such love to anyone who needs help regardless of who they are and where they come from (Legg 2011:25). Loving others is a command that is applied universally and not selectively (Evans 2011:177). In this case, the Teacher told a student that the neighbour was not Jews, but all those who needed his love. Because at that time, 'neighbour' who was understood by the expert in the law (student) was Jewish alone (Wauran 2016:18).

Love is an essential pillar of Teacher pedagogy because it is unconditional, not relational, sacrificial and not selfserving (Sales 2020:13). Love does not start from the object, but it starts from a loving subject. The presence of love transcends the existence of objects and love becomes the fundamental basis of intercultural components. People who have compassion are people who have love. 'Compassion' is an internal outcome in the teaching of IC because people who have 'compassion' are people having intercultural awareness or cultural self-awareness and understanding of other's worldviews. Haas (2019:84) emphasises that a key step towards reaching intercultural competency is gaining an awareness of humans' universal natural tendencies and one's own particular biases and tendencies (self-awareness).

Related to 'compassion', Osborne (2003:56) explains that compassion is not a form of pity that is only satisfied by the expression of sorrow. The feeling of sorrow does not transcend compassion until there is a strong desire to help people with different cultural backgrounds, who need help. Compassion can only be measured through the act itself. In essence, compassion translates our feelings into unselfish deeds and sometimes covers self-sacrifices. Based on compassion, the Samaritan has intercultural consciousness which then encourages a burning desire to assist others (the Jews) without considering the difference of ethnicity and religiosity, acting appropriately, unselfishly and willingly sacrificing for the Jews, not for himself, ethnicity, religion or because of the command, influence or policy of others. Thus, compassion not only eliminates assumptions and prejudices, but it also pays attention to the well-being of others without being selfish in order to meet them, and often involves selfsacrifice (altruism). In line with that, Esler (2000:343) states that compassion transcends the legally recognised ethnic boundary and discrimination when faced with real human needs, and is a more glorious form of human behaviour than just continuing to live within ethnic boundaries.

\section{Student only}

Based on the parable story, there is an interpersonal, intrapersonal, transpersonal and intratextual dialogue between teachers and the student. All of these dialogues invite, motivate and challenge students' active involvement to create a personal interpretation and have an open mind about 'who is my neighbour?' The student answered, 'The one who had compassion on him'. Although the student did not directly answer the Samaritan, he stated that the Samaritan was the one who loved the half-dead Jew. This answer proved that the disciple had understood carefully that the Samaritan had an internal outcome to the Jews for love. On this basis, the student has cultural self-awareness and understanding of Samaritan's worldviews (IC).

Furthermore, the student's answer also indicates that he would do what the Samaritan had performed to the Jews (like and wise) as per the command of the Teacher. The student also realised that he had to appear as an intercultural agent for the other Jews because he was an expert teacher in describing the law for Judaism (Browning 2009:103) and was a Jewish scholar trained to develop the Torah and teaching the pupils verbally and in writing, as well as implementing the law in a Jewish setting (Thia 2005:1).

\section{Conclusion}

Jesus (Teacher) has been an intercultural model before giving intercultural teaching to the student. This indicates that the Teacher has IC because of what the Teacher taught has been performed by the Teacher before. Based on the results of diacognitive analysis, the Teacher designed a model teaching IC that differs from Deardorff's pyramid model of IC. The Teacher puts love as the primary requirement and the basis of three components of IC (attitude, knowledge and skill). While the internal outcome is compassion and external outcomes are to behave and communicate effectively, precisely and wisely to different people of culture (likewise). Besides, the Teacher added one more aspect as the pinnacle of the pyramid, the intercultural agent.

The Teacher used the parable technique as a form of intervention to improve the student's IC (the expert in the law). The parable is the supremacy of the spiritual and the beauty of truth (the unity between the material real and the spiritual ideal) that can attract, encourage and stimulate the active involvement of the student, so that the student can think critically and perform interpretations to discover the real truth of his question 'who is my neighbour?' and his own answer 'the one who had compassion on him'. The parable improves the student's IC, where the student has a cultural self-awareness and understanding of Samaritan's worldviews. The disciple understood that love was the basis of the intercultural action of the Samaritan to the half-dead Jew, and I had to do likewise, even an intercultural agent for the other Jews.

\section{Acknowledgements}

The authors would like to thank Sekolah Tinggi Teologi Ekumene Jakarta, Institut Injil Indonesia, Institut Agama Kristen Negeri Kupang and Universitas Persatuan Guru 1945 NTT that have supported this study, as well as Ferdinant Alexander for their advice in the writing of this manuscript. 


\section{Competing interests}

The authors declare that they have no financial or personal relationships that may have inappropriately influenced them in writing this article.

\section{Authors' contributions}

All listed authors contributed to the writing of this article.

\section{Ethical considerations}

This article followed all ethical standards for research without direct contact with human or animal subjects.

\section{Funding information}

This research received no specific grant from any funding agency in the public, commercial or not-for-profit sectors.

\section{Data availability}

Data sharing is not applicable to this article as no new data were created or analysed in this study.

\section{Disclaimer}

The views and opinions expressed in this article are those of the authors and do not necessarily reflect the official policy or position of any affiliated agency of the authors.

\section{References}

Armstrong, D., Armstrong, A.C. \& Spandagou, I., 2011, 'Inclusion: By choice or by chance?, International Journal of Inclusive Education 15(1), 29-39. https://doi. org/10.1080/13603116.2010.496192

Arshavskaya, E., 2018, 'Promoting intercultural competence in diverse US classroom through ethnographic interviews', Teaching Education 29(2), 194-210. https:// doi.org/10.1080/10476210.2017.1373277

Barrett, M.D., 2011, 'Intercultural competence', EWC Statement Series 2, 23-27.

Batelaan, P., 2003, Intercultural education in the 21st century: Learning to live together, Council of Europe, Strasbours

Bennett, M.J., 2004, 'Becoming interculturally competent', in J.S. Wurzel (ed.), Toward multiculturalism: A reader in multicultural education, pp. 62-77, Intercultural Resource Corporation, Newton, MA

Borg, M., 2011, Jesus: Uncovering the life. Teachings, and relevance of a religious revolutionary, SPCK, London.

Brendel, N., Aksit, F., Aksit, S. \& Schrüfer, G., 2016, 'Multicultural group work on field excursions to promote student teachers' intercultural competence', Journal of Geography in Higher Education 40(2), 284-301. https://doi.org/10.1080/0309826 5.2016.1140731

Browning, W., 2009, Kamus Alkitab, BPK Gunung Mulia, Jakarta.

Byram, M., Gribkova, B. \& Starkey, H., 2002, Developing the intercultural dimension in language teaching: A practical introduction for teachers, Council of Europe, Language Policy Division, Strasbourg.

Deardorff, D.K., 2006, 'Identification and assessment of intercultural competence as a student outcome of internationalization', Journal of Studies in Intercultural Education 10(3), 241-266. https://doi.org/10.1177/1028315306287002

Dodd, C.H., 1961, The parables of the kingdom, Charles Scribner's Sons, New York, NY.

Donahue, J.R., 1988, The Gospel in parable: Metaphor, narrative, and theology in the synoptic Gospels, Fortress Press, Minneapolis, MN.

Efruan, E.M.C. \& Dami, Z.A., 2019, 'The multicultural pedagogy in the parable of the good Samaritan and its contribution to Sundermeier's Intercultural Hermeneutic: A diacognitive analysis', Analisa Journal of Social Science and Religion 4(2), 301-318. https://doi.org/10.18784/analisa.v4i02.836

Efruan, E.M.C., Dami, Z.A., Latupeirissa, D.S. \& Dethan, M.A.P., 2020, 'Multicultura counseling with the technique of parable: A diacognitive analysis', European Journal of Science and Theology 16(1), 165-176.

Esler, P.F., 2000, 'Jesus and the reduction of intergroup conflict: The parable of the good Samaritan in the light of social indentity theory', Biblical Interpretation 8(4), 325-357. https://doi.org/10.1163/156851500750118953
Evans, C.A., 2011, Understanding the Bible commentary series Luke, Baker Books, Grand Rapids, MI.

Feng, J.B., 2016, 'Improving intercultural competence in the classroom: A reflective development model', Journal of Teaching in International Business 27(1), 4-22. https://doi.org/10.1080/08975930.2016.1172540

Freire, P., 2004, Pedagogy of indignation, Paradigm, Boulder, CO

Funk, R.W., Scott, B.B. \& Butts, J.R., 1988, The parables of Jesus: Red letter edition. The Jesus Seminar, Polebridge, Sonoma, CA

Gowindasamy, M., 2017, 'A case study on the implementation of reflective development model in improving intercultural competence among business student in Stamford College', Journal of Education and Practice 8(12), 168-174.

Guberman, D., 2020, 'Teaching intercultural competence through heavy metal music', Arts and Humanities in Higher Education 2, 1-18. https://doi.org/10.1177/ 1474022220903403

Haas, B.W., 2019, 'Enhancing the intercultural competence of college students: A consideration of applied teaching techniques', International Journal of Multicultural Education 21(2), 81-96.

Horne, H.H., 1920, Jesus the master teacher, Association Press, New York, NY.

Howard-Hamilton, M.F., Richardson, B.J. \& Shuford, B., 1998, 'Promoting multicultura education: A holistic approach', College Student Affairs Journal 18, 5-17.

Hoyer, S. \& McDaniel, P., 1990, 'From Jericho to Jerusalem: The good Samaritan from different direction', Journal of Psychology and Theology 18(4), 328-332. https:// doi.org/10.1177/009164719001800403

James, G., Martinez, E., \& Herbers, S., 2015, 'What Can Jesus teach us about student engagement?', Journal of Catholic Education 19(1), 129-154. https://doi. org/10.15365/joce.1901062015

Jin, S., 2015, 'Using Facebook to promote Korean EFL learners' intercultural competence', Language, Learning \& Technology 19(3), 38-51.

Kasmer, L.A., \& Billings, E., 2017, 'Teaching mathematics in multilingual classrooms: Developing intercultural competence via a study abroad program', Frontiers: The Interdisciplinary Journal of Study Abroad 29(2), 1-17. https://doi.org/10.36366/ frontiers.v29i2.389

Knoppers, G.N., 2013, Jews and Samaritans: The origins and history of their early relations, Oxford University Press, New York, NY.

Lee, A., Poch, R., Shaw, M., \& Williams, R., 2012, Engaging diversity in undergraduate classrooms: A pedagogy for developing intercultural competence (ASHE Higher Education Report), Jossey-Bass, San Francisco, CA.

Legg, J., 2011, 'So who is my neighbor?', Foundations An International Journal of Evangelical Theology 61(2), 25-38.

Leung, K., Ang, S., \& Tan, M.L., 2014, 'Intercultural competence', Annual Review of Organizational Psychology and Organizational Behavior 1(1), 489-519. https:// doi.org/10.1146/annurev-orgpsych-031413-091229

Liu, B.L., 2018, 'To train the English action research on the intercultural consciousness of higher vocational students', Science \& Technology Vision 2, 123-124.

MacArthur, J., 2006, The MacArthur New Testament commentary: John 1-11, Moody Chicago, IL.

Matthews, B., 2020, 'The role of reflexive thought in the achievement of intercultura competence', Intercultural Education 31(3), 330-344.

Matusov, E., 2011, 'Authorial teaching and learning', in E.J. White \& M.A. Peters (eds.), Bakhtinian pedagogy: Opportunities and challenges for research, policy and practice in education across the globe, pp. 21-46, Peter Lang, New York, NY.

Mor, M., 1989, Samaritan history: The Persian, Hellenistic and Hasmonaean period, The Samaritans, Tubingen.

Nikulin, D., 2010, Dialectic and dialogue, Stanford University Press, Stanford, CA.

Odağ, Ö., Hannah, R., Wallin, H.R., Karina, K. \& Kedzior, K.K., 2015, 'Definition of intercultural competence according to undergraduate students at an international university in Germany', Journal of Studies in International Education 20(2), 118-139. https://doi.org/10.1177/1028315315587105

Osborne, C.A., 2003, 'What does it mean to be a Good Samaritan?', DVM News Magazine, $54-56$

Pinyol-Jiménez, G. (ed.), 2016, Report on the integration of immigrants in Catalonia 2015, Secretariat for Equality, Immigration and Citizenship, Generalitat de Catalunya.

Ramirez, R.E., 2016, 'Impact on intercultural competence when studying abroad and the moderating role of personality', Journal of Teaching in International Business 27(2-3), 88-105. https://doi.org/10.1080/08975930.2016.1208784

Reinstorf, D.H., 2013, 'The parable of the shrewd manager (Lk 16:1-8): A biography of Jesus and a lesson on mercy', HTS Teologiese Studies/Theological Studies 69(1), 1-7. https://doi.org/10.4102/hts.v69i1.1943

Rodríguez, L.M.G. \& Carranza, T.R., 2017, 'Promoting intercultural competence through cross-cultural projects and literature', in F. Ramos (ed.), Proceedings of the International Colloquium on Languages, Cultures, Identity, in School and Society, pp. 79-85, Loyola Marymount University and Loyola Law School, Los Angeles, CA.

Rule, P., 2015, Dialogue and boundary learning, Sense, Rotterdam.

Rule, P.N., 2017, 'The pedagogy of Jesus in the Parable of the Good Samaritan: A diacognitive analysis', HTS Teologiese Studies/Theological Studies 73(3), 1-8. https://doi.org/10.4102/hts.v73i3.3886

Sales, T.B., 2020, 'Love: A critical pillar in the pedagogy of Jesus', Christian Education Journal: Research on Educational Ministry, 17(2), 1-15. https://doi.org/10.1177/ 0739891320918592 
Santerini, M., 2010, 'Intercultural competence teacher training models: The Italian experience', in $\mathrm{OECD}$ (ed.), Educating teachers for diversity: Meeting the challenge, pp. 185-201, OECD, Paris.

Santoro, N., 2014, 'If I'm going to teach about the world, I need to know the world: Developing Australian pre-service teachers' intercultural competence through international trips', Race Ethnicity and Education 17(3), 429-444. https://doi.org/ international trips', Race Ethnicity ar

Shah-Gordon, R., 2016, 'Intercultural competence development through civic engagement', PhD thesis, Antioch University.

Snodgrass, K.R., 2008, Stories with intent: A comprehensive guide to the parables of Jesus, Eerdmans, Grand Rapids, MI.

Spear, S., 2005, 'The transformation of encultured consciousness in the teachings of Jesus', Journal of Transformative Education 3(4), 354-373. https://doi. org/10.1177/1541344605278009

Stausberg, M. \& Engler, S., 2011, The Routledge handbook of research methods in the study of religion, Routledge, New York, NY

Stein, R.H., 1994, The method and message of Jesus' teaching, Westminster/John Knox, Louisville, KY.

Stockwell, E., 2016, 'Using web-based exploratory tasks to develop intercultural competence in a homogeneous cultural environment', Innovations in Education and Teaching International 53(6), 649-659. https://doi.org/10.1080/14703297.2015.1049642

Teräs, M. \& Lasonen, J., 2013, 'The development of teachers' intercultural competence using a change laboratory method', Vocations and Learning 6(1), 107-134. https://doi.org/10.1007/s12186-012-9087-8

Thia, B., 2005, Tujuh Celaka. Buletin Pillar, viewed 15 March 2021, from http://www. buletinpillar.org/artikel/tujuh-celakabag-i.

Ting-Toomey, S., 2005, 'The matrix of face: An updated face-negotiation theory', in W.B. Gudykunst (ed.), Theorizing about intercultural communication, pp. 71-92, Sage, Thousand Oaks, CA.
Ting-Toomey, S., 2009, 'Intercultural conflict competence as a facet of intercultural competence development: Multiple conceptual approaches', in S.K. Deardorff (ed.), The SAGE handbook of intercultural competency, pp. 100-120, SAGE, Thousand Oaks, CA.

UNESCO, 2006, Unesco guidelines for intercultural education, UNESCO, Paris.

Vermes, G., 2003, The authentic gospel of Jesus, Allen Lane, London.

Voorwinde, S., 2011, 'Do Jews have dealings with Samaritans?', Vox Reformata 70(1), $25-55$.

Wahona, S.W., 1986, Di Sini Kutemukan, BPK Gunung Mulia, Jakarta.

Wauran, Q.C., 2016, Siapakah Sesamaku Manusia?: Sebuah Refleksi Atas Masalah Diskriminasi Etnis Tionghoa Di Indonesia Berdasarkan Kisah Orang Samaria Yang Murah Hati, Sekolah Tinggi Theologia Jaffray, Makasar.

Wibowo, T., 2000, 'Membaca Kisah Orang Samaria Yang Murah Hati Dengan Kacamata Psikologi Sosial', Veritas 1(2), 223-230. https://doi.org/10.36421/ veritas.v1i2.35

Williams, T.R., 2017, 'Using a PRISM for reflecting: Providing tools for study abroad students to increase their intercultural competence', Frontiers: The Interdisciplinary
Journal of Study Abroad 29(2), 18-34. https://doi.org/10.36366/frontiers.v29i2.390

Valdivia, I., Marlene, Á. \& losbel, G.M., 2018, 'Teachers' intercultural competence: A requirement or an option in a culturally diverse classroom?', International Journal of Inclusive Education 22(5), 510-526. https://doi.org/10.1080/13603116.2017.1 377298

Zhang, X. \& Zhou, M., 2019, 'Interventions to promote learners' intercultura competence: A meta-analysis', International Journal of Intercultural Relations 71 31-47. https://doi.org/10.1016/j.ijintrel.2019.04.006

Zimmermann, R., 2008, 'The etho-poietic of the parable of the good Samaritan (LK $10: 25-37)$. The ethics of seeing in a culture of looking the other way', Verbum Et Ecclesia JRG 29(1), 269-292. https://doi.org/10.4102/ve.v29i1.16

Zimmermann, R., 2015, Puzzling the parables of Jesus: Methods and interpretation, Fortress, Minneapolis, MN. 